\title{
Lymphocyte subset analyses in healthy adults vaccinated with yellow fever 17DD virus
}

\author{
Ana Paula dos Santos $/{ }^{++}$, Álvaro Luiz Bertho*, Daniela Capuzzo Dias $/^{++}$, \\ Jaciara Ramos Santos*, Rugimar Marcovist/ ${ }^{+}$
}

\begin{abstract}
Laboratório de Tecnologia Imunológica, Bio-Manguinhos-Fiocruz *Laboratório de Imunoparasitologia, Departamento de Imunologia, IOC-Fiocruz, Av. Brasil 4365, 21045-900 Rio de Janeiro, RJ, Brasil
\end{abstract}

In this study the kinetics of humoral and cellular immune responses in first-time vaccinees and re-vaccinees with the yellow fever 17DD vaccine virus was analyzed. Flow cytometric analyses were used to determine percentual values of $T$ and $B$ cells in parallel to the yellow fever neutralizing antibody production. All lymphocyte subsets analyzed were augmented around the 30th post vaccination day, both for first-time vaccinees and re-vaccinees. $\mathrm{CD}^{+} \mathrm{T}$ cells increased from $30.8 \%(S E \pm 4 \%)$ to $61.15 \%$ (SE $\left.\pm 4.2 \%\right), \mathrm{CD}^{+} \mathrm{T}$ cells from $22.4 \%$ (SE $\left.\pm 3.6 \%\right)$ to $39.17 \%$ (SE $\pm 2 \%$ ) with $43 \%$ of these cells corresponding to $\mathrm{CD}^{+} \mathrm{CD}^{+} \mathrm{R} \mathrm{RO}^{+} \mathrm{T}$ cells, $\mathrm{CD} 8^{+} \mathrm{T}$ cells from $15.2 \%(\mathrm{SE}$ $\pm 2.9 \%)$ to $27 \%(S E \pm 3 \%)$ with $70 \%$ corresponding to $C D 8^{+} C D 45 R O^{+} T$ cells in first-time vaccinees. In revaccinees, the $C D 3^{+} T$ cells increased from $50.7 \%$ ( $S E \pm 3 \%$ ) to $80 \%$ (SE $\pm 2.3 \%$ ), CD4 ${ }^{+}$T cells from $24.9 \%$ (SE \pm $1.4 \%)$ to $40 \%(S E \pm 3 \%)$ presenting a percentage of $95 \% \mathrm{CD}^{+} \mathrm{CD}^{+} \mathrm{R} \mathrm{RO}^{+} \mathrm{T}$ cells, $\mathrm{CD} 8^{+} \mathrm{T}$ cells from $19.7 \%(\mathrm{SE} \pm$ $1.8 \%)$ to $25 \%(S E \pm 2 \%)$. Among $C D 8^{+} C D 38^{+}$T cells there could be observed an increase from 15 to $41.6 \%$ in firsttime vaccinees and 20.7 to $62.6 \%$ in re-vaccinees. Regarding neutralizing antibodies, the re-vaccinees presented high titers even before re-vaccination. The levels of neutralizing antibodies of first-time vaccinees were similar to those presented by re-vaccinees at day 30 after vaccination, indicating the success of primary vaccination. Our data provide a basis for further studies on immunological behavior of the YF 17DD vaccine.

Key words: yellow fever - vaccine - flow cytometry - neutralizing antibodies - lymphocyte subsets

Yellow fever (YF) is a viral illness transmitted by infected mosquitoes (Aedes and Haemagogus genus) with yellow fever virus (YFV), which belongs to the Flavivirus genus, Flaviviridae family (Monath \& Heinz 1996). It remains a serious health problem in endemic areas of tropical and subtropical Africa and South America (Vasconcelos 2003). Since the 19th century, studies about YF immunization have been accomplished (WHO 2001a). The YF 17D vaccine virus strain is one of the most effective and safe vaccines available. Immunization with the $17 \mathrm{D}$ vaccine strain induces a long-term neutralizing antibody response and provides excellent protection against infection with the virulent YFV (Wisseman \& Sweet 1962). In 1937, the production of the YF 17DD vaccine virus substrain was started in Brazil, and has been in continuous use for 60 years (Post et al. 2001). The YFV 17DD vaccine is highly immunogenic and induces neutralizing antibody persistent at least 10 years and in some individuals up to 30 years or more (WHO 2001b).

Although the YF 17D virus strain and the 17DD substrain are the most successful vaccines developed to date, recently, rare cases of postvaccinal neurological disorders have been recorded (Chan et al. 2001, Martin et al. 2001, Vasconcelos et al. 2001). The virus isolates from two fatal cases after 17DD vaccination demonstrated genetic

${ }^{+}$Corresponding author. E-mail: rugimar@bio.fiocruz.br ${ }^{++}$CNPq fellowships

Received 28 July 2004

Accepted 15 April 2005 stability and attenuated phenotype, suggesting that some peculiarities of health status of the host might have been responsible for such adverse events (Galler et al. 2001).

Despite the large literature on the humoral immune response to the YF vaccine virus, few works of the evaluation of cellular immune response, in particular T cell responses have been published (Reinhardt et al. 1998, Co et al. 2002, van der Most et al. 2002). The capacity of vaccines to activate the cellular immune system and induce $\mathrm{T}$ cell memory is an important mechanism of protection against wild-type viral infection. T cells often recognize more conserved epitopes that do not change due to antibody mediated selection pressure (Whitton \& Oldstone 1996, Reinahrdt et al. 1998). Co and collaborators (2002) studying the T cell responses to YFV 17D in four volunteers could observed proliferation and cytolytic responses in all subjects. Their results present CD8 T cell responses directed against at least four different HLA-B35 restricted YFV epitopes.

In order to monitor the immunological behavior of firsttime YF 17DD virus vaccinated and re-vaccinated volunteers, T and B lymphocyte subsets were analyzed by flow cytometry, which is an efficient tool for definition and quantification of lymphocytes employing monoclonal antibodies against cell surface proteins, to determine the importance of knowing the cellular immune response activation related to the YF 17DD vaccine.

\section{MATERIALSAND METHODS}

Volunteers - Seventeen healthy persons with 18 to 55 years of age were vaccinated with the YF 17DD vaccine (Lot 007VFA010Z), produced in Bio-Manguinhos, 
Oswaldo Cruz Foundation, Brazil. Eight individuals, designated first-time vaccinees, had not been vaccinated with the YF 17DD vaccine, and had had no previous infection or contact with the YF wild-type virus. Nine volunteers, designated re-vaccinees, had been vaccinated once or more with the YF 17DD vaccine, 10 or more years before. All volunteers gave their written consent after the study was explained. Each volunteer was injected subcutaneously with $0.5 \mathrm{ml}$ of vaccine. Blood was collected before vaccination (day 0 ) and $2,4,7,10,15,30$, and 60 days post vaccination. The volunteers were advised to report all clinical symptoms and side effects after vaccination. The procedures followed were in accordance with the ethical standards of the responsible committee on human experimentation (CEP/Fiocruz 145/01).

Separation of peripheral blood mononuclear cells (PBMC) - PBMC were obtained by Histopaque (SigmaH8889, St Louis, MS, US) gradient sedimentation, as described elsewhere (Noble et al. 1968, Boyle \& Chow 1969).

Flow cytometric analyses - Freshly isolated PBMC were adjusted to $10^{6}$ cells $/ \mathrm{ml}$ and dual-staining labeled monoclonal antibodies (CD3(IgG1)-FITC/B4-RD1; CD4PC5/CD45RO-PE; CD8-PC5/CD45RO-PE; CD8-PE/CD38FITC) and IgG1-FITC/IgG1-PE isotype antibody (negative control) (Immunotech - Beckmann Coulter, Marseille, France) were used. After incubation for $20 \mathrm{~min}$ at $4^{\circ} \mathrm{C}$, the mixture was washed twice with PBS-azide (PBS containing $0.1 \%$ sodium azide and $2 \%$ fetal bovine serum), and the cells were fixed in $1 \%$ paraformaldehyde (PFA). Stained cells were run in an EPICS ALTRA flow cytometer (Beckmann Coulter, Hialeah, FL, US) equipped with an argon ion laser. Ten thousand events were acquired and analyzed using the Expo32 software (Beckman Coulter). Their forward scatter and side scatter profiles distinguish lymphocytes and monocytes, an electronic gate was created around lymphocytes.

Plaque reduction neutralization test (PRNT) - PRNT were carried out in 96-well plates as described elsewhere (Stefano et al. 1999). In brief, dilutions of the sera ranging from 1:4 to 1:512 were mixed with 1:1200 of the 17DD virus preparation $\left(7.8 \log _{10} \mathrm{PFU} / \mathrm{ml}\right)$. After $1 \mathrm{~h}$ of incubation at $37^{\circ} \mathrm{C}, 100 \mu \mathrm{l}$ of Vero cells $\left(1.6 \times 10^{6}\right.$ cells $\left./ \mathrm{ml}\right)$ were added. A $3 \%$ CMC/199 solution supplemented with 5\% FCS was overlaid after $3 \mathrm{~h}$ of incubation. The cultures were maintained for 7 days at $37^{\circ} \mathrm{C}$ and then the cells were fixed with formaldehyde and stained by violet crystal.

Viremia - For determination of viremia were used the plaque assay (PA) (Wheelock \& Sibley 1965, Reinhardt et al. 1998, Marchevsky et al. 2003) and the reverse transcriptase-polymerase chain reaction (RT-PCR) (Reinhardt et al. 1998) methods, in serum samples before vaccination and on days 2, 4, and 7 after vaccination. RT-PCR products were obtained in the presence of pairs of flavivirus type-specific primers (RG65-antisense, RG36-sense) (Galler et al. 2001), which were kindly provided by Dr Ricardo Galler (Oswaldo Cruz Institute - Fiocruz). Primer pairs were deduced from a RNA sequence from the envelope coding region of the yellow fever virus. The RT-PCR techniques were performed using the Geneamp kit (Applied
Biosystems RNA PCR Core Kit, Roche, Branchburg, New Jersey, US) according to the manufacturer's instructions.

Statistical analyses - Fisher's least significant difference (LSD) procedure was used to evaluate statistically significant differences between means. With this method, there is a 5\% risk of calling each pair of means significantly different when the actual difference equals 0 . Differences were considered as statistically significant if $p$ value were equal or below 0.05 .

\section{RESULTS}

The 17DD vaccine was shown to be very efficient and safe for all volunteers, activating their humoral and cellular immune response, although viremia was not detected through of the methods used (RT-PCR and PA). During the kinetics blood collection in this study, the blood cell count and biochemical tests, including transaminases, did not present alterations after vaccination for any of the volunteers.

None of the first-time vaccinees showed pre-existing neutralizing antibodies (nAb) against the YF 17DD virus substrain $(<256 \mathrm{mUI} / \mathrm{ml}$, limit of antibody detection for our test). Four days after vaccination, low levels of $\mathrm{nAb}$ were detected in 3 of the 8 first-time vaccinees (mean 698 $\mathrm{mUI} / \mathrm{ml}, \mathrm{SE} \pm 301$ ), however, 15 days after vaccination, the $\mathrm{nAb}$ were detected in all of them. High levels of $\mathrm{nAb}$ were reached 30 days after vaccination in this group of volunteers with a slight decrease 30 days later, $30,321 \mathrm{mUI} / \mathrm{ml}$ $(\mathrm{SE} \pm 1300)$ and $22,756 \mathrm{mUI} / \mathrm{ml}$ ( $\mathrm{SE} \pm 4126)$, respectively.

All re-vaccinees had persistent $\mathrm{nAb}$ before re-vaccination, with a mean titer of $5840 \mathrm{mUI} / \mathrm{ml}(\mathrm{SE} \pm 2431)$, despite the interval of, at least, 10 years since the last vaccination. The high standard error achieved was due to the high $\mathrm{nAb}$ titer of one volunteer, above $14,000 \mathrm{mUI} / \mathrm{ml}$, before revaccination. After re-vaccination, $\mathrm{nAb}$ levels increased to a mean titer of $28,526 \mathrm{mUI} / \mathrm{ml}(\mathrm{SE} \pm 2691)$ and $21,598 \mathrm{mUI} / \mathrm{ml}(\mathrm{SE} \pm 3821) 30$ and 60 days later, respectively. Only one volunteer showed no changes in $\mathrm{nAb}$ levels.

The induction of nAb was significantly different between both groups studied among day 0 and day 15 after vaccination $(p<0.05)$ (Fig. 1).

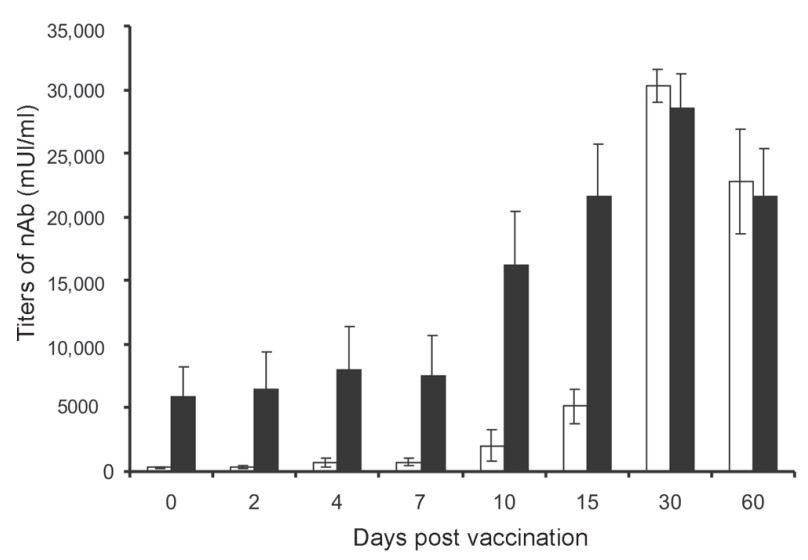

Fig. 1: neutralizing antibodies production following yellow fever 17DD vaccination. The $\square$ and $\square$ represent the means and standard error $( \pm$ SE) of neutralizing antibodies in first-time vaccinee $(n=8)$ and re-vaccinee $(n=9)$ volunteers, respectively; $p<0.05$. 

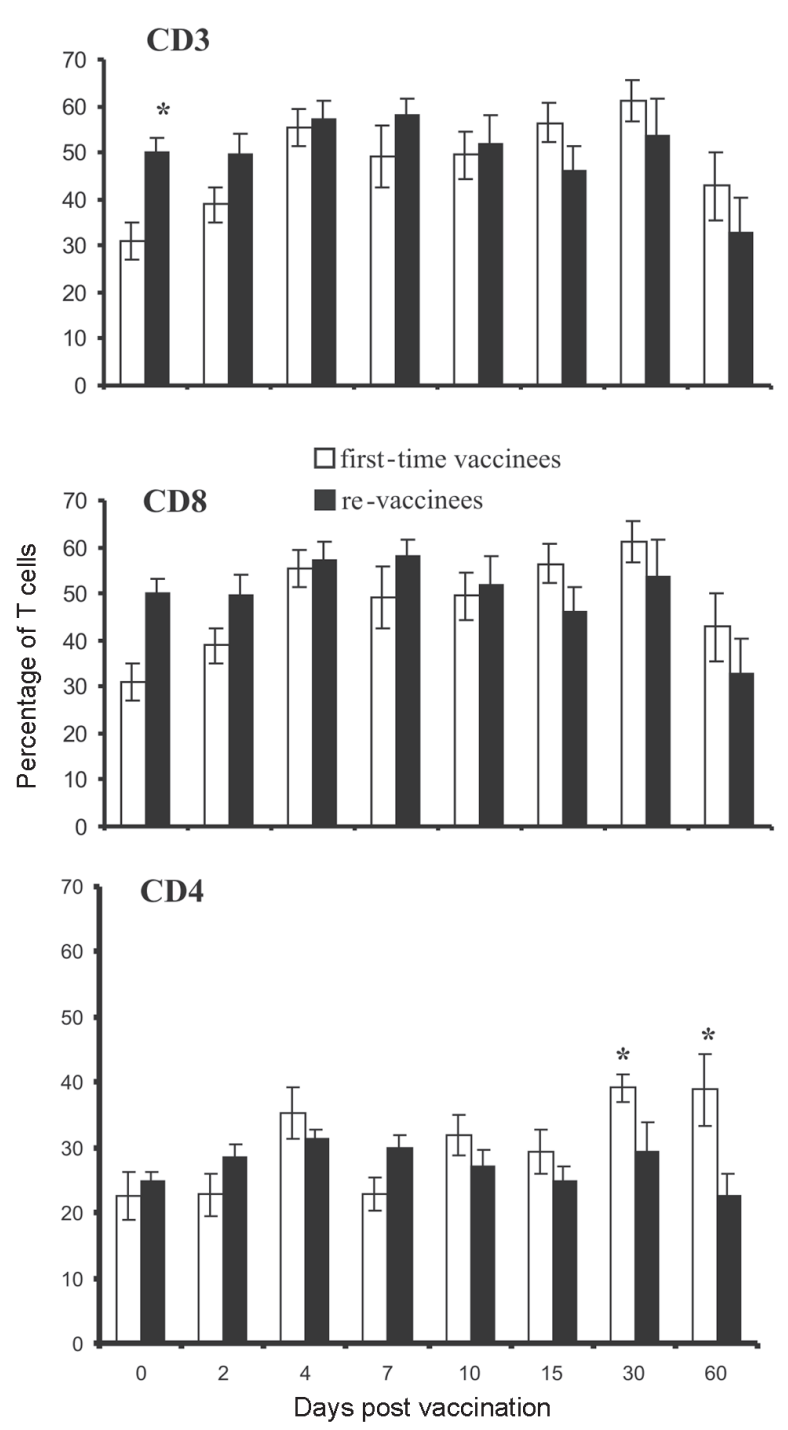

Fig. 2: T cell percentages from peripheral blood mononuclear cells after vaccination in first-time vaccinee $(\square)$ and re-vaccinee ( $\square$ ) volunteers. The bars show the mean of percentages and standard error $( \pm \mathrm{SE})$ of the lymphocyte subsets analyzed; $p<0.05$; $*$ indicates statistically different results between first-time vaccinee and re-vaccinee groups on each day analyzed.

Figs 2, 3, and 4 show the T cell subsets from volunteers vaccinated with the YF $17 \mathrm{DD}$ virus. In all volunteers an increase in $\mathrm{CD}^{+} \mathrm{T}$ cells was observed. In first-time vaccinees, the level of circulating $\mathrm{CD}^{+} \mathrm{T}$ cells has significantly increased, from $30.8 \%$ (SE $\pm 4.0 \%$ ) of the mononuclear cells before vaccination to $61.15 \%(\mathrm{SE} \pm 4.2 \%)$ on the 30th day post vaccination $(p=0.0002)$ and in revaccinees from $50.7 \%(\mathrm{SE} \pm 3.0 \%)$ to $66.5 \%(\mathrm{SE} \pm 2.6 \%)$ on the 7 th day for 6 of the 9 volunteers $(p=0.0001)$ and $80 \%$ $(\mathrm{SE} \pm 2.3 \%)$ on the 30th day after vaccination in the other volunteers $(\mathrm{n}=3)(p=0.0464)$.

In first-time vaccinees a significant increase in the levels of circulating $\mathrm{CD}^{+} \mathrm{T}$ cells was observed. The initial mean in first-time vaccinees increased from $15.2 \%$ (SE \pm $2.9)$ to $27 \%(\mathrm{SE} \pm 3.0 \%$ ) on the 30 th day post vaccination ( $p=0.0276$ ), with $70 \%$ of the cells being identified as memory cells, according to the analysis of the $\mathrm{CD}^{+}$ $\mathrm{CD}_{45 \mathrm{RO}^{+}} \mathrm{T}$ cell subset. Among re-vaccinees, the initial concentration of these cells was $19 \%$ (SE $\pm 1.8 \%$ ) before vaccination and $22.5 \%(\mathrm{SE} \pm 2.0 \%)$ in 5 volunteers between the 4 th and the 10th day $(p=0.2499)$ and $25 \%$ (SE $\pm 2.0 \%$ ) on the 30th day post vaccination in the four other volunteers $(p=0.0083)$ with identification of $90 \%$ of the cells as being $\mathrm{CD}^{+} \mathrm{CD} 45 \mathrm{RO}^{+} \mathrm{T}$ cells in all volunteers, at day 30 . Among the $\mathrm{CD}^{+} \mathrm{CD} 38^{+} \mathrm{T}$ cells, a marker for activated $\mathrm{T}$ cells, a significant increase could be observed, from 15 to $41.6 \%$ in first-time vaccinees $(p=0.0207)$ and from 20.7 to $62.6 \%$ in re-vaccinees $(p=0.0017)$.

Analyzing the levels of $\mathrm{CD}^{+}{ }^{+} \mathrm{T}$ cells, it could be observed that a significant increase in first-time vaccinees occurred, from $22.4 \%(\mathrm{SE} \pm 3.6)$ to $39.17 \%$ (SE $\pm 2.0 \%$ ) on the 30 th day post vaccination $(p=0.0026)$, with $43 \%$ of these cells being identified as $\mathrm{CD} 4^{+} \mathrm{CD} 45 \mathrm{RO}^{+} \mathrm{T}$ cells. The re-vaccinees have presented levels of circulating $\mathrm{CD}^{+} \mathrm{T}$ cells from $24.9 \%$ (SE $\pm 1.4 \%)$ to $35.24 \%$ ( $\mathrm{SE} \pm 1.2 \%$ ) between the 4 th and the 10th day $(n=5)(p=0.1613)$, and to $40 \%(\mathrm{SE} \pm 3.0 \%)$ on the 30 th day post vaccination in the four other volunteers $(p=0.0051)$, presenting a percentage of 90 and $95 \%$ of $\mathrm{CD}^{+}{ }^{+} \mathrm{CD} 45 \mathrm{RO}^{+} \mathrm{T}$ cells, respectively.

The CD4/CD8 ratios were above one (varying from 1.3 to 2.1) with no difference between the two groups studied (Table).

\section{DISCUSSION}

The YF 17DD vaccine, produced in Bio-ManguinhosFiocruz, Brazil, is known to be a safe and efficient vaccine, leading to suitable results with regards to nAb production (Stefano et al. 1999, WHO 2001b, Marchevsky et al. 2003). However, the cellular immune response profile of the YF 17DD vaccine has not been known as yet, although some rare adverse events after vaccination have been suggested as a failure in the cellular immune response of these patients (Galler et al. 2001, Mariannaeu et al. 2001, Vasconcelos et al. 2001).

In this work, we have analyzed some parameters of humoral and cellular immune responses after YF 17DD vaccination.

The volunteers of this study have well tolerated the vaccination. No significant changes were detected in red and white blood cell and platelet counts or in the transaminase levels after vaccination.

The methods used to monitor the viremia, PA and RTPCR, were not able to detect viruses or viral RNA fragments in the sera of the first-time vaccinees or re-vaccinees, despite of these methods were used with success by other authors (Reinhardt et al. 1998). A hypothesis for this lack of detection of viremia could be the high titers of neutralizing antibodies, which would be able to suppress the presence of circulating virus (Wisseman Jr \& Sweet 1962) and the decrease of viral circulation that is prompted by YF 17DD virus, unlike the wild type virus (Monath 1998). In a previous study, the RT-PCR was shown to be more sensitive than PA, it was seen that the RT-PCR detects stretches of virus-specific RNA that may represent only RNA fragments or defective viral particles, as a positive assay does not necessarily reflect the presence of viable virus (Reinhardt et al. 1998). 
All re-vaccinees have presented high titers of persistent neutralizing antibodies before re-vaccination, although they have not been in yellow fever endemic areas within ten years of re-vaccination. These results strengthen the idea of viral presence in lymphatic tissues suggested by other reports (Reeves et al. 1958, Oehen et al. 1992). The titers of $\mathrm{nAb}$ in all re-vaccinees have reached high values on the 30th day after revaccination. The induction of $\mathrm{nAb}$ observed among the first-time vaccinees have indicated the success of the vaccination. The levels of $\mathrm{nAb}$ in this
Isotype control

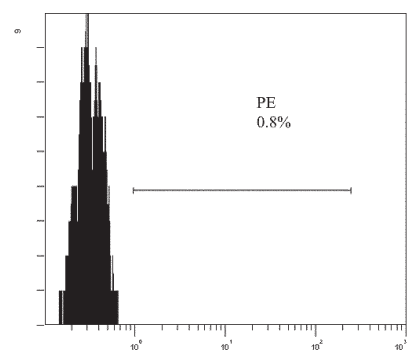

A
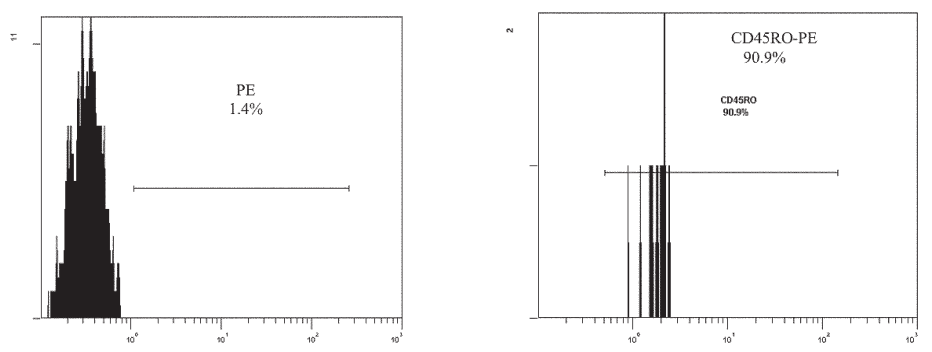

First-time vaccinee

Isotype control

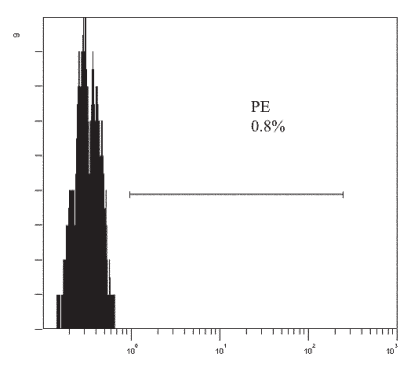

B
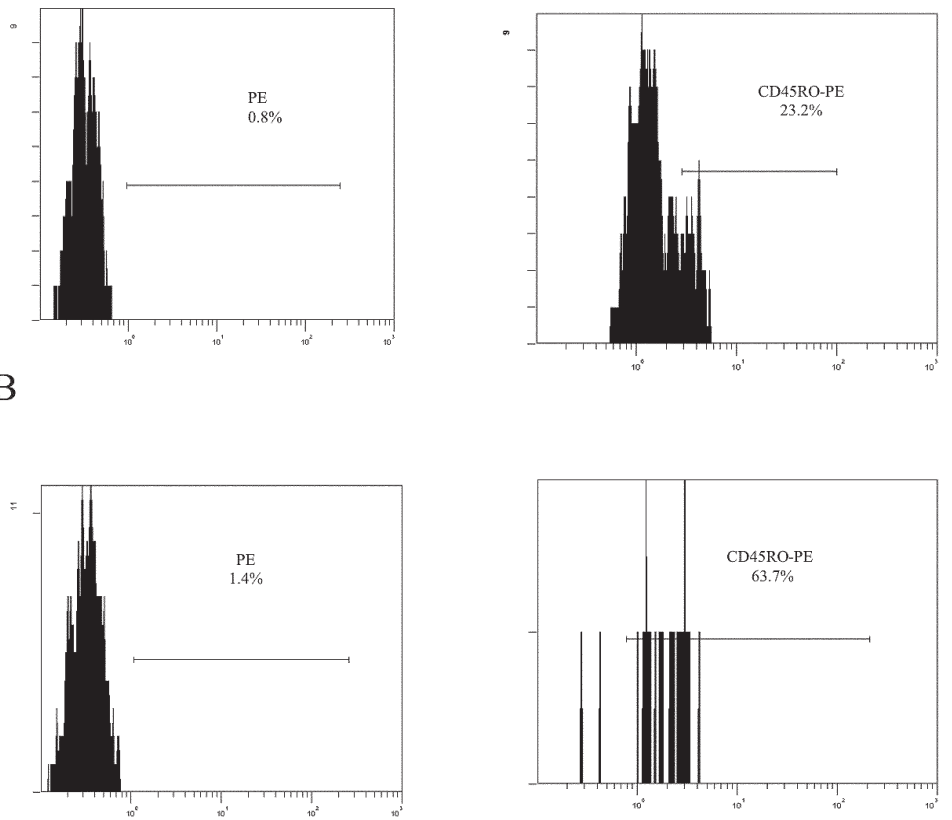

Re-vaccinee

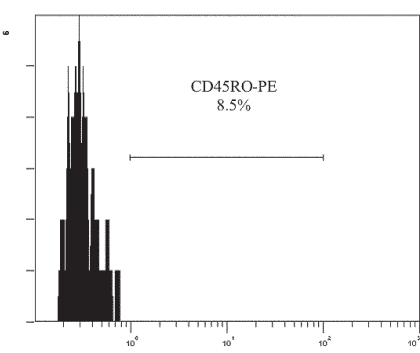

Before

vaccination

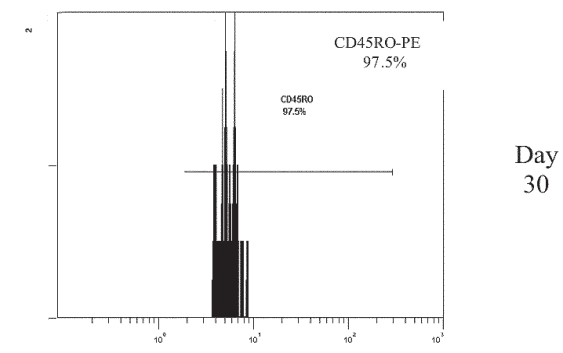

Re-vaccinee

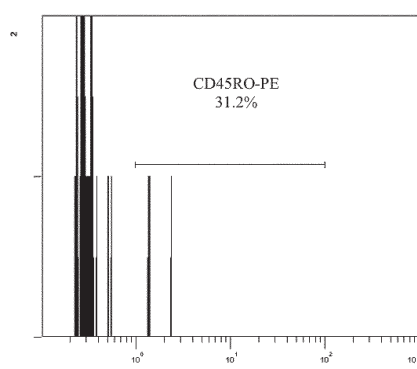

Before vaccination

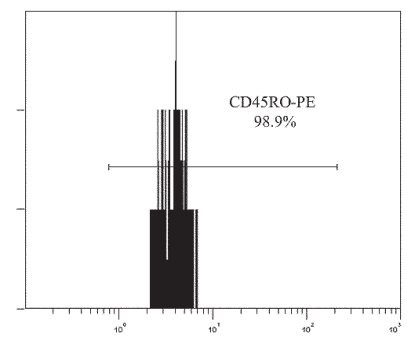

Day 30

Fig. 3: human peripheral blood mononuclear cell-derived lymphocytes, from volunteers before vaccination and 30th day post immunization with yellow fever 17DD virus, were dual-stained with CD8-PC5/CD45RO-PE and CD4-PC5/CD45RO-PE. The histograms represent the percentage of $\mathrm{CD}_{4} \mathrm{RO}^{+}$cells gated on $\mathrm{CD}^{+}(\mathrm{A})$ or $\mathrm{CD}^{+}(\mathrm{B}) \mathrm{T}$ cells on day 0 (before vaccination) and 30 th day after vaccination in first-time vaccinees and re-vaccinees. Isotype antibodies were used as negative control. 
group of volunteers were similar to those shown for the re-vaccinees.

The $\mathrm{CD}^{+} \mathrm{T}$ cell levels were analyzed to evaluate the profile of cellular immune responses in all vaccinated subjects. All volunteers have presented a significant increase in his T cell subset, suggesting an activation of the cellular immune response. With respect to $\mathrm{CD}^{+} \mathrm{T}$ cell counts, it was observed a significant augmentation in all first-time vaccinees and in four re-vaccinees volunteers. This increase of $\mathrm{CD}^{+} \mathrm{T}$ cells was expected due to the importance of these cells in the mechanism of the immune response for intracellular attenuated pathogens vaccinees described by other authors (van der Most et al. 2000, 2002, Co et al. 2002). In our study, the vaccination induced the activation of $\mathrm{CD}^{+} \mathrm{T}$ cells, as could be observed on the significant increase of the $\mathrm{CD} 8^{+} \mathrm{CD} 38^{+} \mathrm{T}$ cells in all volunteers.
$\mathrm{CD} 4^{+} \mathrm{T}$ cells are involved in several steps in the mechanics of immune response, as antibodies and cytokine production, among other events during the type- 2 immune response, through B cells activation and posterior plasma cell differentiation (Mills et al. 2000, Liu \& Chambers 2001). As was observed in this study, all first-time vaccinees have presented a significant increase in their numbers of $\mathrm{B}$ cells (data not shown) and in the $\mathrm{CD} 4^{+} \mathrm{T}$ cell subsets. In the group of the re-vaccinees, only four volunteers have presented a significant increase in the latter lymphocyte subset. It is important to note that these volunteers also had their $\mathrm{CD} 8^{+} \mathrm{T}$ cells augmented significantly, as discussed above.

The CD4/CD8 ratio did not demonstrate difference between the two analyzed groups. The number of $\mathrm{CD}^{+} \mathrm{T}$ cells were more than $\mathrm{CD}^{+} \mathrm{T}$ cells, showing a normal activation of the immune system after vaccination, to the
Isotype control
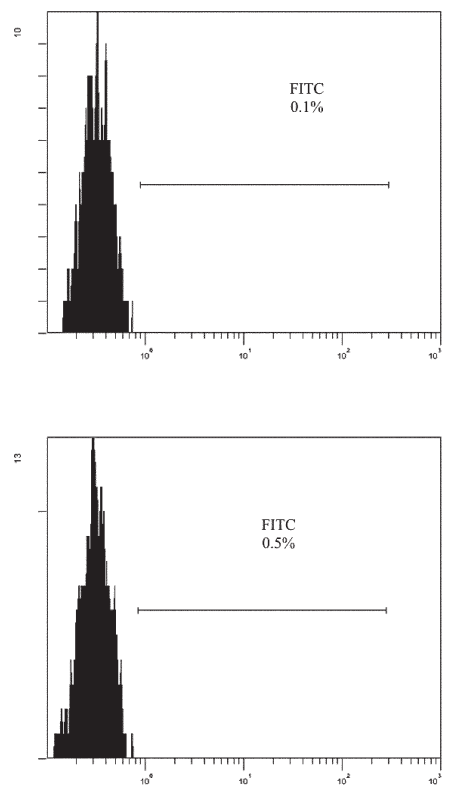

First-time vaccinee
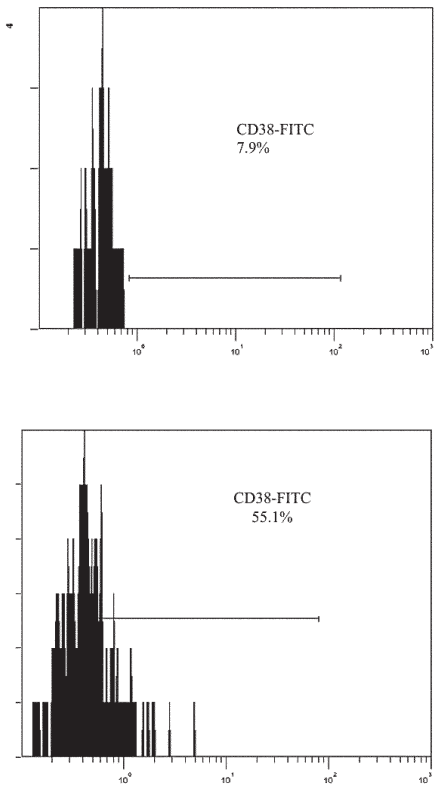

Re-vaccinee

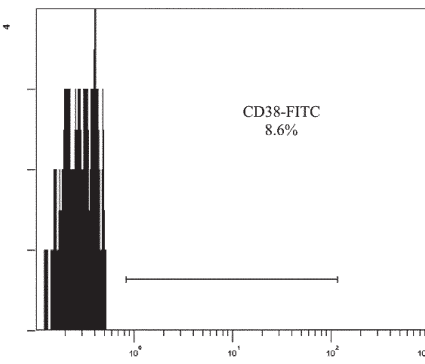

Before vaccination

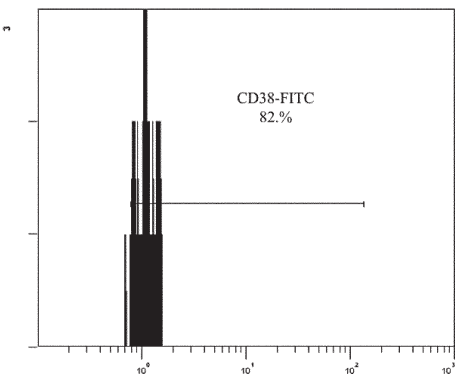

Day

30

Fig. 4: human peripheral blood mononuclear cell-derived lymphocytes, from volunteers before vaccination and 30th day post immunization with yellow fever 17DD virus, were dual-stained with CD8-PE/CD38-FITC. The histograms represent the percentage of CD38 ${ }^{+}$cells gated on $\mathrm{CD} 8^{+} \mathrm{T}$ cells, in first-time vaccinees and re-vaccinees, day 0 and 30th day after vaccination.

TABLE

Percentage values and ratio of CD4 and CD8 T cell subsets

\begin{tabular}{|c|c|c|c|c|c|c|}
\hline \multirow{2}{*}{$\begin{array}{l}\text { Days post } \\
\text { vaccination }\end{array}$} & \multicolumn{3}{|c|}{ First-time vaccinees } & \multicolumn{3}{|c|}{ Revaccinees } \\
\hline & $\% \mathrm{CD} 4$ & $\% \mathrm{CD} 8$ & $\mathrm{CD} 4 / \mathrm{CD} 8$ & $\% \mathrm{CD} 4$ & $\% \mathrm{CD} 8$ & $\mathrm{CD} 4 / \mathrm{CD} 8$ \\
\hline 0 & 22.5 & 15.3 & 1.5 & 24.9 & 19.7 & 1.3 \\
\hline 2 & 22.8 & 18.2 & 1.3 & 28.4 & 20.5 & 1.4 \\
\hline 4 & 35.2 & 20.7 & 1.7 & 31.3 & 21.3 & 1.5 \\
\hline 7 & 22.7 & 17.7 & 1.3 & 29.7 & 17.4 & 1.7 \\
\hline 10 & 32.0 & 22.5 & 1.4 & 27.0 & 20.3 & 1.3 \\
\hline 15 & 29.3 & 18.2 & 1.6 & 24.7 & 14.3 & 1.7 \\
\hline 30 & 39.1 & 24.2 & 1.6 & 29.4 & 20.7 & 1.4 \\
\hline 60 & 38.8 & 18.0 & 2.1 & 22.7 & 15.4 & 1.5 \\
\hline
\end{tabular}

Average of percentage values of $\mathrm{CD}^{+}$and $\mathrm{CD}^{+} \mathrm{T}$ cell subsets from 8 first-time vaccinees and 9 re-vaccinees with yellow fever $17 \mathrm{DD}$ virus. For standard error see Fig 2. 
opposite of the infection with flavivirus which presents CD4/CD8 ratio inversion (Lei et al. 2001, Liu et al. 2002).

Not all re-vaccinees have presented significant increase in the levels of $\mathrm{CD}^{+}$and $\mathrm{CD}^{+} \mathrm{T}$ cells, but the percentage of their activated cell subsets $\left(\mathrm{CD} 4^{+} \mathrm{CD} 45 \mathrm{RO}^{+}\right.$ and $\mathrm{CD}^{+} \mathrm{CD}^{+} 5 \mathrm{RO}^{+}$cell markers) was more highly augmented than those of the first-time vaccinees. This result has suggested that the re-vaccinees were able to answer to the YF 17DD virus without need for a co-stimulation.

The importance of the $\mathrm{CD} 4^{+} \mathrm{T}$ cell and $\mathrm{CD} 8^{+} \mathrm{T}$ cell subsets in $\mathrm{nAb}$ production could be observed through analysis of the results from one of the volunteers with leucopoenia, anemia and thrombocytopenia before vaccination. In this volunteer, the increase of the cell subsets analyzed did not occur and the nAb induction was observed later than in the other volunteers.

Despite of several studies carried out analyzing the levels of lymphocyte subset standards in healthy humans, it is known that such values are not constant, some factors can affect lymphocyte subset counts, such as stress, physical exercises, smoking and alcohol (Goff et al. 1985, Uppal et al. 2003).

The data presented herein provide a basis for further studies on immunological response to the YF 17DD vaccine in human beings. Therefore, a study of the $\mathrm{T}$ cell immune response activation associated to lymphocyte proliferation and cytokine production in YF vaccination is underway.

\section{ACKNOWLEDGMENTS}

To Centro de Pesquisa Hospital Evandro Chagas-Fiocruz for measuring blood cells counts and serum biochemical assays and the technical assistance of Adriana de Oliveira Honorato, Bio-Manguinhos-Fiocruz. To Dr Vera Bongertz from Departamento de Imunologia, Instituto Oswaldo Cruz-Fiocruz for reading the manuscript.

\section{REFERENCES}

Boyle W, Chow A 1969. Isolation of human lymphocytes by a Ficoll barrier method. Transfusion 9: 151 - 155.

Chan RC, Penney DJ, Little D, Carter IW, Roberts JA, Rawlinson 2001. Hepatitis and death following vaccination with 17D-204 yellow fever vaccine. The Lancet 358: 121-126.

Co MDT, Terajima M, Cruz J, Ennis FA, Rothman AL 2002. Human cytotoxic T lymphocyte responses to live attenuated 17D Yellow Fever vaccine: Identification of HLAB35-restricted CTL epitopes on nonstructural proteins $\mathrm{NS} 1, \mathrm{NS} 2 \mathrm{~b}, \mathrm{NS} 3$, and the structural protein E. Virology 293: $151-163$.

Galler R, Pugachev KV, Santos CLS, Ocran SW, Jabor AV, Rodrigues SG, Marchevsky RS, Freire MS, Almeida LFC, Cruz ACR, Yamamura AMY, Rocco IM, Travassos da Rosa ES, Souza LTM, Vasconcelos PFC, Guirakhoo F, Monath TP 2001. Phenotypic and molecular analyses of yellow fever 17DD vaccine viruses associated with serious adverse events in Brazil. Virology 290: 309-319.

Goff LK, Habeshaw JA, Rose ML, Gracie JA, Gregory W 1985. Normal values for the different classes os venous blood mononuclear cells defined by monoclonal antibodies. J Clin Pathol 38: 54-59.
Lei HY, Yeh TM, Liu HS, Lin YS, Chen SH, Liu CC 2001. Immunopathogenesis of dengue virus infection. $J$ Biomed Sci 8: 377-388.

Liu CC, Huang KJ, Lin YS, Yeh TM, Liu HS, Lei HY 2002. Transient CD4/CD8 ratio inversion and aberrant immune activation during dengue virus infection. J Med Virol 68: 241-252.

Liu T, Chambers TJ 2001. Yellow fever virus encephalitis: Properties of the brain-associated T-cell response during virus clearance in normal and gamma interferon-deficient mice and requirement for CD4+ lymphocytes. $J$ Virol 75: 2107-2118.

Marchevsky RS, Freire MS, Coutinho ESF, Galler R 2003. Neurovirulence of yellow fever 17DD vaccine vírus to rhesus monkeys. Virology 316: 55-63.

Marianneau P, Georges-Courbot MC, Deubel V 2001. Rarity of adverse effects after 17D yellow-fever vaccination. The Lancet 358: 84-85.

Martin M, Tsai TF, Cropp B, Chang G-JJ, Holmes DA, Tseng J, Shieh W-J, Zaki SR, Al-Sanouri I, Cutrona AF, Ray G, Weld LH, Cetron MS 2001. Fever and multisystem organ failure associated with 17D-204 yellow fever vaccination a report of four cases. The Lancet 358: 98-104.

Mills CD, Kincaid K, Alt JM, Heilman MJ, Hill AM 2000. .M1/M-2 Macrophages and the Th1/Th2 Paradigm. J Immunol 164: 6166-6173.

Monath TP 1998. Yellow fever In S Plotkin, EA Montmer Junior (eds), Vaccine, 3rd ed., WB Saunders, Philadelphia, p. $815-879$.

Monath TP, Heinz FX 1996. Flaviviruses. In BN Fields, DM Knipe, PM Howley (eds), Fields Virology, 3rd ed., Lippincott, Raven Publishers, Philadelphia, New York, p. 1009-1016.

Noble PB, Cutts JH, Carroll KK 1968. Ficoll flotation for the separation of blood leukocyte types. Blood 31: 66-73.

Oehen S, Waldner H, Kiinding TM, Hengartner H, Zinkernagel RM 1992. Antivirally protective cytotoxic T cell memory to lymphocytic choriomeningitis virus is governed by persisting antigen. J Exp Med 176: 1273-1281.

Post PR, Carvalho R, Freire MS, Galler R 2001. The early use of yellow fever vírus strain 17D for vaccine production in Brazil - A review. Mem Inst Oswaldo Cruz 96: 849-857.

Reeves WC, Huston GA, Bellamy RE, Scrivany RP 1958. Chronic latent infections of birds with western equine encephalomyelitis virus. Proc Soc Exp Biol Med 97: 733736.

Reinhardt B, Jaspert R, Niedrig M, Kostner C, L'age-Stelvr J 1998. Development of viremia and humoral and cellular parameters of immune activation after vaccination with yellow fever virus strain 17D: a model of human flavivirus infection. J Med Virol 56: 159-167.

Stefano I, Sato HK, Pannuti CS, Omoto TM, Mann G, Freire MS, Yamammura AMY, Vasconcelos PFC, Oselka GW, Weckx LW, Salgado MF, Noale LFO, Souza VAUF 1999. Recent immunization against measles does not interfere with the sero-response to yellow fever vaccine. Vaccine 17: 1042-1046.

Uppal SS, Verma S, Dhot PS 2003. Normal values of CD4 and 
CD8 lymphocyte subsets in healthy Indian adults and the effects of sex, age, ethnicity, and smoking. Cytometry Part $B$ (Clinical Cytometry) 52B: 32-36.

van der Most RG, Harrington LE, Giuggio V, Mahar PL, Ahmed R 2002. Yellow fever virus 17D envelope and NS3 proteins are major targets of the antiviral $\mathrm{T}$ cell response in mice. Virology 296: 117-124.

van der Most RG, Murali-Krishna K, Ahmed R, Strauss JH 2000. Chimeric yellow fever/dengue virus as a candidate dengue vaccine: quantitation of the dengue virus-specific CD8 T-cell response. J Virol 74: 8094-8101.

Vasconcelos PFC 2003. Febre amarela. Rev Soc Bras Med Trop 36: 1-29.

Vasconcelos PFC, Luna EJ, Galler R, Silva LJ, Coimbra TL, Barros VLRS, Monath TP, Rodrigues SG, Laval C, Costa ZG, Vilela MFG, Santos CLS, Papaiordanou CMO, Alves VAF, Andrade LD, Sato HK, Rosa EST, Froguas GB, Laçava E, Almeida LMR, Cruz ACR, Rocco IM,
Santos RTM, Oliva OFP, Brazilian Yellow Fever Vaccine Evaluation Group 2001. Serious adverse events associated with yellow fever 17DD vaccine in Brazil: a report of two cases. The Lancet 358: 91-97.

Wheelock EF, Sibley WA 1965. Circulating virus, interferon and antibody after vaccination with the 17D strain of yellow fever virus. New England J Med 273: 194-198.

Whitton JL, Oldstone MBA 1996. Immune response to viruses In BN Fields, DM Knipe, PM Howley (eds), Fields Virology, 3rd ed., Lippincott, Raven Publishers, Philadelphia, New York, p. 345-374.

Wisseman Jr CL, Sweet BH 1962. Immunological studies with group B arthropod-borne viruses, III. Response of human subjects to revaccination with 17D strain yellow fever vaccine. Am J Trop Med Hyg 11: 570-575.

WHO 2001a. http://www.who.int/emc/diseases/yellowfever/

WHO 2001b. http://www.who.int/vaccines/intermediate/ yellowfever.htm 
